\title{
Effects of Long-Term (7 Years) Adoption of Conservation Agriculture and Nutrient Management Practices on the Soil Properties, System Crop and Water Productivity and Farm Economics of a Maize-Chickpea Rotation
}

Vijay Pooniya ( $\nabla$ vpooniya@gmail.com )

Indian Agricultural Research Institute

R.R. Zhiipao

Indian Agricultural Research Institute

Niraj Biswakarma

Indian Agricultural Research Institute

S.L. Jat

ICAR-Indian Institute of Maize Research

Dinesh Kumar

Indian Agricultural Research Institute

C.M. Parihar

Indian Agricultural Research Institute

K Swarnalakshmi

Indian Agricultural Research Institute

Achal Lama

Indian Agricultural Statistics Research Institute

A.K. Verma

Indian Agricultural Research Institute

Debasish Roy

Indian Agricultural Research Institute

Kajal Das

Central Research Institute for Jute and Allied Fibers

K. Majumdar

African Plant Nutrition Institute

T. Satyanarayana

International Plant Nutrition Institute

R.D. Jat

Chaudhary Charan Singh Haryana Agricultural University

P.C. Ghasal

Indian Institute of Farming Systems Research

Hardev Ram

National Dairy Research Institute

Rajkumar Jat

Borlaug Institute for South Asia

Amlan Nath

Indian Agricultural Research Institute

\section{Research Article}

Keywords: CEP, CA, MCR, RDF, PNB

Posted Date: December 31st, 2020

DOI: https://doi.org/10.21203/rs.3.rs-134630/v1

License: () (1) This work is licensed under a Creative Commons Attribution 4.0 International License. Read Full License 


\section{Abstract}

Conservation agriculture (CA)-based practices have been promoted and recouped, as they hold the potential to enhance farm profits besides a consistent improvement in soil properties. The CA-based crop establishment practices (CEP) along with adequate fertilizer inputs in the diversified maize-chickpea rotation (MCR) could be a profitable choice to sustain the crop production of Indo-Gangetic plains in the posterity. Therefore, a seven years' field experiment consisting of three CEP viz., zero till flatbed (ZTFB), permanent beds (PNB), conventional system (CT) along with the three nutrient management practices; nutrient expert assisted: site-specific nutrient management (NE®), recommended fertilization (RDF), and farmers' fertilizer practice (FFP), was carried out from 2013-2020 in a sandy loam soil of the north-western Indo-Gangetic plains. Seven years' mean maize grain yield under the ZTFB (4.34 Mg ha ${ }^{-1}$ ) and PNB (4.37 $\left.\mathrm{Mg} \mathrm{ha}^{-1}\right)$ was significantly $(p<0.05)$ higher than the CT $\left(3.79 \mathrm{Mg} \mathrm{ha}^{-1}\right)$. The NE® and RDF had $25.7 \%$ and $22.3 \%$ greater maize grain yield than the FFP, respectively. Similarly, ZTFB and PNB had $12.2 \%$ and $21.5 \%$ greater chickpea seed yield, respectively over the CT. The NE® and RDF gave $12.1 \%$ and $8.4 \%$ higher chickpea seed yield over the FFP, respectively. The CA-based CEP (ZTFB / PNB) produced 13.9-17.6\% (seven years' mean) higher maize grain equivalent yield (MGEY) compared to the CT, while NE® and RDF had 10.7-20\% higher MGEY than the FFP. Furthermore, the PNB and ZTFB gave $28.8 \%$ and $24 \%$ additional net returns than the CT, while NE® and RDF had $22.8 \%$ and $17.4 \%$ greater returns, respectively over the FFP. The mean data showed that PNB had $7.5 \%$ and $30.8 \%$ greater system water productivity (SWP) than the ZTFB and CT, the NE $®$ and RDF had $20 \%$ and $14 \%$ greater SWP than the FFP, respectively. After harvest of the $7^{\text {th }}$ year maize, the PNB and ZTFB had 2.3-4.1\% (0.0-0.20 m soil layers) lower bulk density ( $\rho$ b) than the CT, however NE ${ }^{\circ}$ and RDF had $1-1.9 \%$ lower $\rho$ b compared to the FFP. The CEP had a significant $(p<0.05)$ impact on the soil organic carbon $(\mathrm{OC})$ in $0.0-0.20 \mathrm{~m}$ soil layers but it remained unaffected due to the nutrient management beyond $0.10 \mathrm{~m}$ soil depth. Microbial biomass carbon (MBC) increased by $8-19 \%(0.0-0.50 \mathrm{~m}$ soil layers) in the ZTFB / PNB over the CT, and by $7.6-11.0 \%$ in the NE® / RDF over FFP. The sustainability yield index (SYI) was also greater under the CA-based CEP and with the NE® or RDF compared to the CT practices. Hence, the present study suggests that the CA-based CEP coupled with the NE® or RDF could enhance the yields, farm profits, soil properties of the maize-chickpea rotation, thereby, could sustain the production in long-run.

\section{Introduction}

The importance of conventional rice-wheat system (RWS) in the Indo-Gangatic Plains (IGPS) in securing the food and nutrition has been negated due to the greater water requirement and exacerbating soil fertility status ${ }^{1}$ coupled with the higher production costs and inefficient inputs usages ${ }^{2,3}$. The ever-changing climate and exaggerating soil degradation poses a constant threat to the sustainability of the conventional farming practices. To redress these effects, conservation agriculture (CA)-based practices have been propounded to restore the degrading soil fertility, enhance the resource use efficiency (RUE) and improve the crops yield ${ }^{4}$.

Maize (Zea mays L), an emerging versatile crop with wider adaptability and photo-insensitivity under different ecological scenario, may replace the rice crop in the wet season. It has potential to address issues such as food and nutritional security ${ }^{5}$, water scarcity and climate change ${ }^{4}$. Also, there is an increasing demand of maize in the industrial sector with the increased population pressure ${ }^{6}$. Similarly, chickpea (Cicer arietenium) is a protein rich (17-22\% of total dry seed mass, and best among all legume proteins) legume, grown on an area of $\sim 14.5 \mathrm{~m}$ ha with an annual production of $\sim 11.5 \mathrm{~m} t \mathrm{globally}$, with the most production centered in India ${ }^{7}$. Maize-based rotations with improved soil and crop management practices have proved a better alternative over the intensive conventional RWS through realization of better system yields, enhanced soil properties, better utilization and savings of irrigations along with the reduced labor costs $^{8}$. The development of single cross high yielding maize hybrids coupled with the energy efficient chickpea genotypes have given an ample scope for diversifying the existing cereal-cereal rotations. In India, maize-chickpea rotation (MCR), is important and next to the maize-wheat, maize-mustard only. The inclusion of chickpea in a cereal based rotation helps in sustaining the soil health and system yields further. It may also help in saving the water over the RWS.

Conventional mode of crop production has been deemed un-sustainable, as it is less energy efficient, consumes more water with lesser productivity, employs improper usage of inputs and obsolete crop establishment methods 9,10 . Consequently, poor residue management under conventional tillage (CT) practices compelled the farmers either to burn them in-situ or feed to the cattle ${ }^{11,12}$. Moreover, intensive tillage not only degrades the soil organic matter (SOM) due to the enhanced oxidation but also disrupts the organic carbon (SOC), hence impairs the soil properties ${ }^{13}$. The mismanagement and exacerbating environment through CT practices could be reoriented by adhering to the CA-based practices i.e., no- or minimum tillage, residue retention and diversifying the crops, thereby, enhancing the soil health and yields ${ }^{14,15}$. Also, adoption of the CA-based crop establishment practices (CEP) (ZTFB / PNB) in different rotations significantly improves the water use efficiency ${ }^{16}$, system yields ${ }^{12}$ and net returns ${ }^{13,17,10}$. Besides, it improved the soil physical properties ${ }^{18,19}$, built-up the $\mathrm{SOC}^{20,21}$, and enhanced the soil MBC ${ }^{22}$.

Nutrient management in MCR under the CA-based systems needs to be enumerated considering the contribution through the residue retention, atmospheric $\mathrm{N}$ fixation and the residual soil fertility rather than the usual blanket recommendation. To mitigate and cope up the exacerbating issues, nutrients need to be applied as per the crop demands and its potential yielding ability. Hence, the NE® based site-specific nutrient management principles focusing on the balanced and crop-need based nutrition ${ }^{23,24,25}$ would help in increasing the nutrient use efficiency and provide more profits. This is fundamentally based on the internal nutrient efficiency (INE), and is predicted considering the QUEFTS (quantitative evaluation of the fertility of tropical soils) model. The International Plant Nutrition Institute (IPNI) and International Maize and Wheat Improvement Center (CIMMYT) have developed the user-friendly NE $B$ that could enhance and sustain the productivity apace with the improved soil health $26,27,28$. Initially, it was hypothesized that using the NE® would enhance the yields and reduce the fertilizer use. Further, this hypothesis was validated at multi-locations $(n=104)$ field trials conducted in the southern Indian states by the All India Coordinated Research Project (AICRP) and IPNI on maize following NE® principles. The positive results of these validation trials showed that the field-specific fertilizer recommendations based on $\mathrm{NE} \circledast$ not only increased the crops yields, but also optimized the fertilizer application rates ${ }^{29,30,31}$.

However, the impacts of CA-based CET (ZTFB / PNB) coupled with the precise nutrient management using NE® in MCR are yet to be evaluated thoroughly. Therefore, this study was undertaken for seven years' (2013-2020) to assess the impacts of the conservation agriculture and nutrient management practices 
on the system yields, farm economics and soil properties in the MCR of north-western India.

\section{Results}

\section{Weather parameters during the study period}

During the cropping seasons (July-April), the highest rainfall of $1368 \mathrm{~mm}$ was received in 2013-14, followed by $1230.2 \mathrm{~mm}$ in $2016-17$, while only $600-900$ mm was received in 2014-15, 2015-16, 2017-18, 2018-19 and 2019-20. Most of the rainfall was received during the three months (July-September), accounting for nearly $80 \%$ of the total rainfall. During winters, the common occurrence of the western disturbances in the north-western India resulted in a very less rainfall. The amount of rainfall received during the October-April was least in 2015-16 (22 mm) and 2017-18 (39.4), while 100-350 mm was received in rest of the years (Supplementary Table 1).

\section{Seven years' trends and pooled grain and stover yields of maize}

Crop establishment practices (CEP) had a significant $(p<0.05)$ effect on the grain and stover yields of maize over the study years. In this study, initial years showed a reduction in the grain yield, but from third year onward, the yield increased significantly in the CA plots over the CT. Grain yield under the ZTFB and PNB significantly outperformed the CT across the years, except during 2014 and 2015, whereas, the CT had similar yield to the ZTFB in 2013. (Fig. 2a). Across the years, nutrient expert (NE $\AA$ ) and the recommended fertilization (RDF) resulted in similar yield, but being significantly superior to the FFP. However, the NE $\AA$ had significantly higher yield over the RDF during 2019 (Fig. 2b). On the basis of the pooled data, the PNB and ZTFB had similar grain yield, which was 13.3\% and $12.7 \%$ higher over the CT, respectively. Similarly, the NE® and RDF recorded significantly higher pooled grain yield, which was $25.7 \%$ and $22.3 \%$ higher than the FFP, respectively (Table 2).

In all the years, the ZTFB and the PNB had similar stover yields, but being significantly higher than the CT (Fig. 2c), and had $12.4 \%$ and $12.2 \%$ higher pooled yield over the CT, respectively. Furthermore, the stover yield under the NE® and RDF significantly outdo the FFP across the years, whereas the NE® had significantly greater stover yield than the RDF, except during 2017 and 2018 (Fig. 2d). The seven years' average showed that the NE $§$ and RDF produced $25.8 \%$ and $17.6 \%$ greater stover yields than the FFP, respectively (Table 2 ).

\section{Seven years' trends and pooled seed and stover yields of chickpea}

In all the years, the PNB produced maximum seed yield, except in 2016-17 (Fig. 3a), followed by the ZTFB. The NE® was the best, except during 2017-18 and 2018-19, with no difference among the FFP, RDF and NE® in 2014-15, 2015-16, 2017-18 and 2018-19 (Fig. 3b). The PNB had 10.8\% and 21.5\% greater pooled seed yield than the ZTFB and CT, respectively (Table 2).

The PNB and ZTFB had similar chickpea stover yield, being significantly $(p<0.05)$ greater than the CT, but in 2014-15, 2015-16 and 2019-20, the ZTFB was at par to the CT (Fig. 3c). In contrast, the NE® recorded significantly greater stover yield than the RDF and FFP, but was at par with the RDF in $2019-20$ (Fig $3 d$ ). The PNB had registered maximum stover yield, which was significantly higher over the ZTFB and CT. However, the NE® plots had significantly $11.9 \%$ and $19.3 \%$ greater stover yield over the RDF and FFP, respectively (Table 2).

\section{System productivity as maize grain equivalent yield (MGEY)}

The PNB had significantly $(p<0.05)$ greater MGEY over the ZTFB (2013-14, 2018-19) and CT, but in 2014-15 and 2015-16; no significant difference among CEP practices was observed. Thereafter, in 2016-17, the ZTFB had significantly higher MGEY (10.7-21.4\%) compared to the PNB and CT; while in 2017-18 and 2019-20, the ZTFB and PNB had similar yields (Fig. 4a). In nutrient management, the NE® and RDF were comparable for the MGEY across the years, but significantly greater than the FFP. However, in 2019-20, the RDF and FFP had similar MGEY. Averaged across the seven years, the ZTFB and PNB produced 13.9-17.6\% greater MGEY than the CT, however the NE® and RDF gave 10.7-20\% (seven years' mean) greater MGEY than the FFP (Fig. 4b).

\section{Interaction effect (CEP $\times$ nutrient) on the MGEY}

CEP and nutrient management had a significant $(p<0.05)$ interaction effect on the MGEY across the years. In 2013-14, the PNB-NE® had maximum MGEY, and at par to the PNB-RDF and CT-RDF. Similarly, in 2014-15, the PNB-NE® produced the highest MGEY, but did not differ to the PNB-RDF, ZTFB-NE $B$, ZT-RDF and CT-NE®. In 2015-16, the PNB-NE® had similar yield to all the treatment combinations, except CEP practices with FFP. In contrast, the ZTFBNE $\circledast$ had the greatest MGEY during 2016-17, 2017-18 and 2019-20. However, it was at par to the RDF and NE $®$, irrespective of the CEP practices during 201617, 2017-18 and 2019-20. Whereas in 2018-19, the PNB-NE® exhibited the highest MGEY, and significantly greater than the ZTFB-FFP and CT (Table 3). The results of the current study also suggested that the NE® and RDF either with the PNB or ZTFB tended to have relatively more MGEY than the other conventional based CEP practices.

\section{Farm economics}

The seven years' mean data indicated that the CT (US\$ $639.9 \mathrm{ha}^{-1}$ ) was the most expensive CEP, which was $15.3 \%$ and $16.9 \%$ costlier than the PNB (US\$ 541.7 $\mathrm{ha}^{-1}$ ) and ZTFB (US\$ $531.6 \mathrm{ha}^{-1}$ ), respectively. Likewise, the RDF (US\$ $582.7 \mathrm{ha}^{-1}$ ) accounted for the highest cultivation cost, closely followed by the NE $\AA$ (US\$ $576.7 \mathrm{ha}^{-1}$ ), being $5 \%$ and $4.1 \%$ higher over the FFP (US\$ $553.3 \mathrm{ha}^{-1}$ ), respectively. In all the years, the PNB had highest net returns, whereas, in 2016-17, the ZTFB accounted for the greater returns. However, the ZTFB and PNB did not differ for the system net returns, except during 2013-14, 2016-17 and 2018-19.

The PNB (US\$ $1671.1 \mathrm{ha}^{-1}$ ) and ZTFB (US\$ $1565.9 \mathrm{ha}^{-1}$ ) had generated $28.8 \%$ and $24 \%$ higher net returns than the CT (US\$ $1189.8 \mathrm{ha}^{-1}$ ), respectively. Similarly, the NE® (US\$ 1635.9 ha $^{-1}$ ) and RDF (US\$ 1528.4 ha-1) had 22.8\% and 17.4\% greater net returns than the FFP (US\$ 1262.9 ha-1) plots (Table 4), 
respectively.

\section{Sustainable yield index (SYI)}

Among the CEP in maize, the PNB had the greater SYI, but being at par to the ZTFB, which was $15 \%$ and $13.2 \%$ greater than the CT. Further, SYI was the highest under the $\mathrm{NE}{ }^{\circledR}$, similar to RDF, being $29.1 \%$ and $25.6 \%$ greater than the FFP. In case of chickpea, the SYI was highest under the PNB, which was $12.4 \%$ and $23.6 \%$ higher than the ZTFB and CT, respectively. The SYI in the NE® and RDF were at par, being 8.9-12.8\% greater than the FFP (Table 2).

\section{System water productivity (SWP)}

During the first three years' of the study, the plots under the PNB (10.1-11.5 $\left.\mathrm{kg} \mathrm{ha}^{-1} \mathrm{~mm}^{-1}\right)$ led to the highest SWP, which was significantly higher over the ZTFB $\left(8.7 \mathrm{~kg} \mathrm{ha}^{-1} \mathrm{~mm}^{-1}\right)$ and CT $\left(7.2-7.7 \mathrm{~kg} \mathrm{ha}^{-1} \mathrm{~mm}^{-1}\right)$, respectively. Whereas, fourth year onward, the PNB $\left(8.4-16.1 \mathrm{~kg} \mathrm{ha}^{-1} \mathrm{~mm}^{-1}\right)$ had similar SWP to the ZTFB (9.7-15.7 kg ha-1 $\mathrm{mm}^{-1}$ ), but significantly higher than the CT (5.7-11.1 $\mathrm{kg} \mathrm{ha}^{-1} \mathrm{~mm}^{-1}$ ) (Fig. 5a). Among nutrient management treatments, the NE $\AA$ and RDF had similar SWP, except during 2013-14, 2016-17 and 2019-20 however, it was 20\% and 14\% (seven years' mean) greater than the FFP (Fig. 5b).

\section{Soil properties - bulk density ( $\mathrm{\rho b})$, organic carbon $(\mathrm{OC})$ and microbial biomass carbon (MBC)}

After harvest of the seventh season maize, soil samples were collected from the 0.0-0.50 m soil depth (Fig. 6a). Among the CEP, the PNB and ZTFB had significantly lower $\rho \mathrm{b}$ than the CT up to the $0.20 \mathrm{~m}$ soil depth. The decrement was to the tune of $2.3-4.1 \%$ over the CT, though there was no difference in the ZTFB and PNB. In contrast, beyond the $0.20 \mathrm{~m}$ soil depth, $\rho$ b did not differ significantly among the CEP practices (Fig. $6 \mathrm{a}$ ). Across the soil sections, nutrient management practices were at par for $\rho \mathrm{b}$ (Fig. $6 \mathrm{~b})$. The CEP had a significant $(p<0.05)$ impact on the soil OC up to the $0.20 \mathrm{~m}$ soil depth, the ZTFB and PNB were at par, but greater than the CT in the 0.0-0.20 m depth. However, there was no difference in the 0.20-0.50 m soil section (Fig. $6 \mathrm{c}$ ). The NE ${ }^{8}$ and RDF had the similar values for the $\mathrm{OC}$, but significantly greater than the FFP in the 0.0-0.10 m depth, however, the SOC did not differ among the nutrient management beyond the $0.10 \mathrm{~m}$ soil depth (Fig. $6 \mathrm{~d}$ ).

At the silking stage of the seventh season maize, the ZTFB and PNB had similar values for the MBC, but significantly greater by $8.3-20.3 \%$ than the CT in the 0.0-0.30 m soil depth (Fig. 6e). Likewise, the NE® and RDF had similar MBC, but significantly greater than the FFP in the $0.0-0.10 \mathrm{~m}$ depth. However, beyond the $0.10 \mathrm{~m}$ soil depth, these practices did not show a significant influence on the MBC (Fig. 6f).

For the OC stock $\left(\mathrm{Mg} \mathrm{ha}^{-1}\right)$, the ZTFB and PNB had 15.5-16\% higher OC stock in the upper $0.10 \mathrm{~m}$ soil layer, but in the $0.10-0.50 \mathrm{~m}$ soil depth, CEP practices did not have a significant impact on the OC stock, though relatively greater values across the depths were recorded in the ZTFB / PNB than the CT plots. Nevertheless, the total OC stock up to the $0.50 \mathrm{~m}$ soil depth was $9.5-12.3 \%$ greater under the CA-based CEP than the CT (Fig. 7a). The NE $B$ had the highest OC stock across the soil layers $(0.0-0.50 \mathrm{~m})$, which was similar to the RDF, but $6.2 \%$ greater than the FFP (Fig. $7 \mathrm{~b}$ ). Also, the MGEY had strong relationship with the OC stock under the CA-based CEP $\left(r^{2}=0.87 ; p<0.05\right)$ and the nutrient management $\left(r^{2}=0.94 ; p<0.05\right)$.

\section{Discussion}

Diversifying the existing dominant rice-wheat system (RWS) towards maize-based, particularly maize followed by legumes under the CA-based CEP (ZTFB / PNB) along with the balanced nutrition, could enhance and stabilize yields and the farm profits ${ }^{32,12}$, besides the improved soil properties in long-run ${ }^{33}$. RWS in the IGPs of South Asia is facing challenges of exaggerating decline in the ground water table and the input use efficiencies ${ }^{34}$. Henceforth, maize-chickpea rotation (MCR) has potential to combat the twin challenges of the declining ground water by $30-40 \mathrm{~cm}$ year ${ }^{-135}$, and the import of pulses. In this study, the CAbased CEP had greater maize (12-13\%) and chickpea (12-21\%) yields across the years over the CT. It could be associated with the commendatory soil temperature / moisture conditions ${ }^{36}$, improved soil properties ${ }^{13,37}$, better water and nutrient uses ${ }^{18}$ besides, amalgamating the effects of the residue retention ${ }^{38}$. Further, these practices also help in the better retention and infiltration of the water and favour better growing conditions that may have resulted in the greater crops yields.

Despite the wide variability in the precipitation (excess / deficit ranis) during the study, the PNB / ZTFB with residues recorded 16.5-17.6\% greater MGEY than the $\mathrm{CT}$, it is of course, due to the improved levels of SOM / SOC stocks and other soil properties, reinforcing previous finding in the cereal-based rotations ${ }^{19,9,10}$ In this study, a relatively higher mean yields were exhibited in the NE®, however being comparable to the RDF. The yield differences in the NE® and RDF plots could be due to the variation in the fertilizer rates, besides the NE® entailed applications of the balanced and location-specific, which is fundamentally based on the nutrient carrying capacity, thereby it may have enhanced the internal nutrient efficiency ${ }^{19,39,12}$. Possibly, optimal nutrition would have led to the better partitioning of the photosynthates, thereby, more vigorous plant growth with the stiffer rooting and greater resistance against the abiotic stresses ${ }^{40}$. Residual fertility in the NE® and RDF was outlined with the higher chickpea yield than the FFP. Results of multi-location trials in the South Asia had shown that the NE ${ }^{\circledR}$ gave greater yields under the CA than the CT system $30,24,41$.

Feasibility of any technology / management practice could be assessed ultimately through the farm economics. In this study, the CT incurred US\$ $84-123$ ha

${ }^{1}$ greater cultivation cost compared to the ZTFB / PNB. This higher cost in CT was mainly attributed to the additional tillage ${ }^{10}$, apart from higher labour cost needed for extra intercultural operations. On the contrary, increment in the returns under the ZTFB / PNB was to the tune of US\$ $380-481$ ha-1 over the CT. Indeed, the CT plots had the higher farm cultivation cost with the lower MGEY, which in turn reflected in the lower net returns ${ }^{10,42,43}$. Greater net returns under the NE® could be due to a balanced and crop need based fertilizer application ${ }^{24,25}$ resulting in more yields, and the returns. The comparative field studies $(n=82)$ of the NE® with the state recommendation and FFP in the Southern India, reasoned out that, farmers risk could well be reduced, when the NE ${ }^{8}$ was 
adopted, as it directs and provides proper and the balanced rate of fertilizers ${ }^{30}$. Hence, optimized nutrient use apace with the higher yields and profitability under the maize and maize-based rotations.

With respect to SWP, the ZTFB and PNB had $25.6 \%$ and $30.9 \%$ greater values than the CT, which could be ascribed to the better soil moisture regimes due to the surface residue retention coupled with a higher yield gains ${ }^{37,44}$. Furthermore, higher OC stock in the CA-based CET enhanced the moisture retention and opportune time for the water movement in soil ${ }^{45,46}$, hence it facilitates a greater water and nutrient acquisition and ultimately SWP.

The major impacts of the CA-based CEP is conspicuous through higher SOM, especially in the top soil layers apace with the better soil structural stability and biological diversity in contrast to the CT systems ${ }^{47}$. After seven years', the ZTFB and PNB with residues improved the OC content by $18-20 \%$ and total OC stock by $15-16 \%(0.0-0.10 \mathrm{~m}$ depth) than the CT. This would be associated with a better physical protection of particulate organic matter, greater amount of $\mathrm{C}$-residues remain on the soil surface coupled with lesser turnover of macro-aggregates as well as minimal contact between residue and soil ${ }^{48}$. Perhaps, extensive tillage reduces OC, as it breaks open the previously protected SOM leading to the increased microbial decay ${ }^{49,50}$, as observed under the CT system. The implications of the higher $\mathrm{OC}$ under the $\mathrm{NE} \circledast$ and RDF could well be attributed to the proper growth and development of the crop, hence greater above / below-ground biomass production, and eventually the increases in SOM over the FFP.

The effect of the CA-based CEP on the bulk density $(\rho \mathrm{b})$ had shown contradictory results, with some studies reported higher $\rho \mathrm{b}^{51,52}$, on the contrary, some had reported lower $\rho \mathrm{b}^{53}$ or no changes ${ }^{54,55}$ relative to the CT system. Nevertheless, in our study the ZTFB / PNB with residues brought down soil $\rho \mathrm{b}$ by $2.3-4.1 \%$ in the top 0.0-0.20 m soil layer, while the nutrient management did not differ for soil $\rho \mathrm{b}$. The lower $\rho \mathrm{b}$ associated with the residues retention leads to a greater soil faunal activities ${ }^{53,51}$, thereby, resulting in better soil aggregation and porosity. In contrast, the increased $\rho$ b under the CT, is due to the compaction particularly in the plough soil layer ${ }^{13,19}$. The MBC depicts nutrient cycling ability of a soil under different management practices ${ }^{56,57}$ in concurs with the SOM content. The CA-practices coupled with the NE® / RDF favours build-up of the SOC through, rhizo-deposition of root stubbles ${ }^{58,39}$, that certainly increased the $\mathrm{MBC}^{59}$ and crop yields ${ }^{60,61}$. Besides, the greater SOM would expedite the soil MBC and other biological activities ${ }^{62}$. This seven years' study clearly indicates a synergy between the CA-based CEP and NE® or RDF through improvements in yields, MGEY, farm returns and SWP apart from the soil properties. Also, this is well synthesised by a greater SYI, hence could be propounded for its adoption at present and in the posterity.

\section{Conclusions}

The CA-based CEP (ZTFB / PNB) apace with the enhanced resource use-efficiency should be a norm, not the exception, as clearly outlined in our seven years' experiment, wherein, the ZTFB / PNB with the NE® or RDF exceled for the system yields, net returns, SWP, $\rho$ b, OC and SYI. The seven years' mean showed that the MGEY under the ZTFB and PNB increased by $13.9-17.6 \%$, respectively compared to the CT, however, the NE® and RDF registered $10.7-20 \%$ greater MGEY than the FFP. Furthermore, the CA-based CEP along with the NE® or RDF gave an additional net return of US\$376-481 ha-1 $\mathrm{yr}^{-1}$ and US\$265-373 ha-1 $\mathrm{yr}^{-1}$ (seven years' av.) than the CT-FFP, respectively. Also, these practices significantly improved the OC stock (15-16\%) and MBC (8-19\%) with lower $\rho$ b (2.3$4.1 \%)$ in the top soil layers. The improved soil properties coupled with the greater yields, was well substantiated with the simultaneous improvement in SWP under the ZTFB (7.5\%) and PNB (30.8\%). The greater SYI also signified the superiority and sustainability of the rotation in the long-run. Thus, the ZTFB / PNB with the NE® or RDF in the maize-chickpea rotation can be well adopted in the semi-arid Indian ecologies to realize its several benefits under the changing climate.

\section{Materials And Methods}

\section{Experimental site}

A field experiment on the maize-chickpea rotation (MCR) was established during the rainy season of 2013 at the research field of the ICAR-Indian Agricultural Research Institute ( $\left.28^{\circ} 38^{\prime} \mathrm{N} ; 77^{\circ} 09^{\prime} \mathrm{E} ; 228.6 \mathrm{~m} \mathrm{MSL}\right)$, New Delhi, India. Prior to the establishment of this study, a uniformity field trial on wheat was conducted during the winters of 2012-2013 (November-April). The climate of the region is semi-arid and experiences the dry-hot summers and cold winters. During the growing season of maize (July-October) and chickpea (October-April), the maximum rainfall of $1368 \mathrm{~mm}$ was received in 2013-14, while the lowest of only $604.6 \mathrm{~mm}$ in 2017-18. On an average, $\sim 80 \%$ of the total rainfall was received from the south-west monsoon (July-September), and the average relative humidity across the years ranged between $69-87 \%$. The minimum and maximum temperatures during the cropping period ranged from $5-28^{\circ} \mathrm{C}$ and $18-38^{\circ} \mathrm{C}$, respectively (Supplementary Table 1). The Typic Haplustept sandy loam soil of the experimental site had $7.31 \mathrm{pH}, 0.40 \%$ Walkley-Black carbon ${ }^{63}, 159.9 \mathrm{~kg}^{-1}{ }^{-1}$ alkaline $\mathrm{KMnO}_{4}$ oxidizable- $\mathrm{N}^{64}, 15.6 \mathrm{~kg} \mathrm{ha}^{-1} \mathrm{NaHCO}_{3}$ extractable-P ${ }^{6}$, and $161.3 \mathrm{~kg}$ ha ${ }^{-1} \mathrm{NH}_{4} \mathrm{OAc}$ extractable- $\mathrm{K}^{66}$.

\section{Experimental treatment details}

This field experiment consisted of the combinations of three CEP; zero till flatbed (ZTFB), permanent beds (PNB) and conventional tillage (CT) in main-plots, and three nutrient management practices; farmers' fertilizer practices (FFP), recommended fertilization (RDF), and nutrient expert assisted-site specific nutrient management $(\mathrm{NE} \circledast$ ) in sub-plots . Split-plot design was employed for the fixed plot experiment with three replicates during the entire study period (Table 1). Prior to the start of the experiment, the field was deep ploughed using chisel plough $(0.30-0.45 \mathrm{~m})$ and laser levelled. The CT plots involved one ploughing $(0.25-0.30 \mathrm{~m})$, followed by harrowing / rotavator $(0.15-0.20 \mathrm{~m})$ and then levelling, while for the ZTFB, no ploughing was accomplished. Initially, the PNB were prepared using the ridge maker $(0.67 \mathrm{~m})$, and subsequently the disc coulter once in a year before the maize sowing for the reshaping of the beds in during the each following crop seasons. The gross plot size under each CEP practices was $20 \mathrm{~m} \times 8.5 \mathrm{~m}$. Maize at maturity was harvested from $0.40 \mathrm{~m}$ height and standing residues retained in the field under the ZTFB / PNB plots. Similarly, the chickpea residues $\sim 2.5 \mathrm{Mg} \mathrm{ha}^{-1}$ (root stubbles along with the above ground stover) on dry weight basis were retained in the plots (Fig. 1). 
A quality protein maize hybrid 'HQPM1' was used for the experiment, which was later replaced by the hybrid 'PMH1' in 2017. In each cropping season, the maize seeds were dibbled manually in the rows at a spacing of $0.67 \times 0.20 \mathrm{~m}$ during the first week of July. Similarly, sowing of the chickpea genotype 'Pusa 372 ' was done at the end of October in each year i.e., after the maize harvest. Under the RDF practice, full dose of phosphorous (P) by di-ammonium phosphate (DAP) and potassium (K) using muriate of potash along with the nitrogen (N) were applied as basal to both the maize and chickpea crops, after that two equal N splits to maize were applied at the knee-high and flowering stages. The fertilizer doses for FFP were based on the Participatory Rural Appraisal (PRA) i.e., how most of the farmers' in the region follow fertilization to the crops. While, for NE® treatment, fertilizer rates / splits were followed as per the $\mathrm{NE} \circledast$ software, available at the http://www.ipni.net. Fertilizers were placed basally in the top soil layer, while the required $\mathrm{N}$ was top dressed in bands near to the rows (side dressing). Since there is no NE® for chickpea, hence, fertilizers were applied as per the RDF in the NE® sub-plots. The non-selective herbicide glyphosate at $1 \mathrm{~kg} \mathrm{ha}^{-1}$ was sprayed about a week before the sowing of the crops both in the ZTFB / PNB plots. A pre-emergence (2 days after sowing, DAS) spray of atrazine at $0.75 \mathrm{~kg} \mathrm{ha}^{-1}$ to maize and pendimethalin at $0.75 \mathrm{~kg} \mathrm{ha}^{-1}$ to chickpea was applied, manual weedings were done in the CT. Crop protection practices such as pest and disease management were followed as per the requirement of both the crops. Irrigation water was applied considering the rainfall pattern coupled with critical crop stages, in which maize crop received three to six irrigations, while for chickpea it was one to two per crop season.

\section{Soil sampling and processing}

Five soil samples were collected from the $0.0-0.30 \mathrm{~m}$ depth (June 2013) for initial analysis, and in 2019 (after harvest of $7^{\text {th }}$ season maize) from different soil sections i.e., $0.0-0.10,0.10-0.20,0.20-0.30,0.30-0.40$ and $0.40-0.50 \mathrm{~m}$ up to $0.50 \mathrm{~m}$ depth using the core. The samples were shade dried and ground gently using the wooden pestle and mortar, sieved in a $2 \mathrm{~mm}$ sieve and stored in the air tight polythenes for further analysis of soil properties. For soil MBC analysis, the moist soil samples were collected using the tube auger from $0.0-0.50 \mathrm{~m}$ depth at $0.10 \mathrm{~m}$ intervals at the silking stage of maize. Finely sieved soil samples were stored at $5^{0} \mathrm{C}(18-24 \mathrm{~h})$ for $\mathrm{MBC}$ analysis.

\section{Soil organic carbon}

The soil organic carbon (SOC) was determined by the chromic acid wet oxidation method ${ }^{63}$. The finely ground and sieved soil from the different depths ( 0.0 $0.10,0.10-0.20,0.20-0.30,0.30-0.40$ and $0.40-0.50 \mathrm{~m}$ ) was used for its determination. The SOC in $0.10 \mathrm{~m}$ intervals up to $0.50 \mathrm{~m}$ soil depth was computed by using Eq. (1) ${ }^{67}$.

$\operatorname{SOC}$ stock $\left(\mathrm{Mg} \mathrm{ha}^{-1}\right)=\operatorname{SOC}(\%) / 100 \times \mathrm{d}(\mathrm{m}) \times \rho \mathrm{b}\left(\mathrm{Mg} \mathrm{m}^{-3}\right) \times \mathrm{a}(\mathrm{ha})(1)$

Where, $\mathrm{d}$ denotes the soil depth $(\mathrm{m})$ and $\mathrm{a}$ is the area (ha)

\section{Soil bulk density}

Soil bulk density $(\rho \mathrm{b})$ was measured from the different soil sections to a profile depth of $0.50 \mathrm{~m}$, and five samples were collected randomly from the each plot using the core sampler i.e., $0.05 \mathrm{~m} \mathrm{~d}, 0.05 \mathrm{~m}$ h. The collected samples were then dried at $105^{\circ} \mathrm{C}$ for $48-72 \mathrm{~h}$ until a constant weight reached, and then the soil $\rho \mathrm{b}\left(\mathrm{Mg} \mathrm{m}^{-3}\right)$ was computed using Eq. $(2)^{4}$.

$\rho \mathrm{b}=\mathrm{M} s / \mathrm{V} c$

Where, Ms indicates dry weight of the sample $(\mathrm{Mg})$, and $\mathrm{V} c$ is the volume of the core $\left(\mathrm{m}^{3}\right)$

\section{Soil microbial biomass carbon (MBC)}

The fumigation extraction ${ }^{68}$ method was employed to analyse the MBC in soil samples. The pre-weighed soil samples were taken in a closed capped amber colour bottle and fumigated with the ethanol free chloroform. The un-fumigated samples were also taken in a transparent capped bottle and maintained. Both the fumigated and non-fumigated samples were incubated in the dark for $24 \mathrm{~h}$, after which fumigated samples were evaporated by opening the cap and exposing it to the sun for $\sim 20-25 \mathrm{~min}$. and later in a hot air oven at $50{ }^{\circ} \mathrm{C}$ for $\sim 20 \mathrm{~min}$. The processed samples were added $0.5 \mathrm{M} \mathrm{K}_{2} \mathrm{SO}_{4}$ (soil: extractant $1: 4$ ) and kept on a mechanical shaker for $30 \mathrm{~min}$. and soil suspension was filtered using the Whatman No.42 filter paper. The carbon content was determined through dichromate digestion superseded by back titration with $0.05 \mathrm{~N}$ ferrous ammonium sulphate, then the MBC content was computed using the Eq (3).

$\operatorname{MBC}\left(\mu \mathrm{g} \mathrm{C} \mathrm{g}^{-1}\right.$ soil $)=\mathrm{EC} \times 2.64$

Where, $E C=(C$ in fumigated soil $-C$ in un-fumigated soil $)$

\section{Yield measurements}

During the seven years of the experimentation, the crop yields were estimated from the net plot area ( $9 \mathrm{~m} \times 8 \mathrm{~m}$ ), leaving the border rows in both the crops. The border plot area was harvested first, and then the net plot area for recording the grain / seed yields. The harvested maize cobs were sundried for $45-50 \mathrm{~d}$ and the stover for about a month in the open field conditions, and then threshed by a mechanical thresher. The chickpea was harvested manually, and the harvested produce was sundried, then threshed using a tractor drawn pull man thresher. For grain yield, the moisture content was adjusted to $12 \%$ in both the crops. The stover / stalk yields were obtained by subtracting the grain / seed yields from their respective total biomass yield. To estimate the system productivity of MCR, chickpea seed yield was converted into the maize grain equivalent yield (MGEY) as given in the Eq (4) ${ }^{10,61}$.

Page 6/15 
$\operatorname{MGEY}\left(\mathrm{Mg} \mathrm{ha}^{-1}\right)=\mathrm{Y}_{\mathrm{m}}+\left\{\left(\mathrm{Y}_{\mathrm{c}} \times \mathrm{P}_{\mathrm{c}}\right) \div \mathrm{P}_{\mathrm{m}}\right\}$

Where, MGEY= maize grain equivalent yield $\left(\mathrm{Mg} \mathrm{ha}^{-1}\right), Y_{m}=$ maize grain yield $\left(\mathrm{Mg} \mathrm{ha}^{-1}\right), Y_{c}=$ chickpea seed yield $\left(\mathrm{Mg} \mathrm{ha}^{-1}\right), \mathrm{P}_{\mathrm{m}}=\mathrm{price}$ of maize grain $(U S \$ \mathrm{Mg}$

${ }^{1}$ ) and $\mathrm{P}_{\mathrm{C}}=$ price of chickpea seed (US\$ $\mathrm{Mg}^{-1}$ )

\section{Farm economics}

The total production cost was computed based on the variable costs for each treatment. The cost included, human labour employed for different field operations, rental land value, use of machineries viz. tractor, plough, planter, thresher, etc., fertilizers, seed, pesticides, other plant protection chemicals, irrigations, and harvesting. The gross returns included the market value of both grain / seed and stover / stalk, wherein the value of grain / seed was as per the minimum support price set by the Government of India during the respective seasons. The net returns were computed using the formula: net returns (US\$ ha-1) $=$ [gross returns $\left(\mathrm{US} \mathrm{ha}^{-1}\right)$ - cost of cultivation (US $\left.\$ \mathrm{ha}^{-1}\right)$ ]. Systems net returns were estimated by summing the net returns of both the crops (maizechickpea rotation). The economics data (production costs / returns) were then converted from the Indian rupee (INR) to the US dollar (US\$) based on the exchange rate during the respective years.

\section{System water productivity (SWP)}

The SWP for the MCR across the years was computed by taking into account the total water input (irrigation + rainfall) during the growing seasons. The amount of rainfall water received was computed using the manual rain gauge data of meteorological observatory adjacent to the field. Irrigation depth was measured by using an ordinary scale meter which had $\mathrm{mm}$ and $\mathrm{cm}$ marks. In each plot, the depth of water was measured at 10 selected spots immediately after the irrigation. Based on the rainfall pattern, three to six irrigations were applied to the maize at the critical growth stages, while for chickpea one to two irrigations per crop season were given at the late vegetative / pod development stages. The water productivity $\left(\mathrm{kg} \mathrm{ha}^{-1} \mathrm{~mm}^{-1}\right)$ was computed as per the Eq. $(5)^{69}$. The system water productivity (SWP) was worked out by adding the water productivity of both the crops.

Water productivity $=$ grain yield $\left(\mathrm{kg} \mathrm{ha}^{-1}\right) /$ total water applied $(\mathrm{mm})$

\section{Sustainable yield index (SYI)}

${ }^{70,71}$ described the SYI as a quantitative measure of the sustainability of any agricultural system / practice. Using this concept, the sustainability could be interpreted on the basis of the standard deviation $(\sigma)$, where the lower values of the $\sigma$ indicate the higher sustainability and vice-versa. Total crop productivity of maize and chickpea under different the CEP and nutrient management was computed based on the seven years' mean yield data. SYI was computed based on the Eq. (6) ${ }^{70}$.

$\mathrm{SYI}=\left(-\overline{\mathrm{y}}_{\mathrm{a}}-\sigma_{\mathrm{n}}{ }_{1}\right) / \mathrm{Y}^{-1} \mathrm{~m}$

Where, $-\bar{y}_{a}$ is the average yield of crops across the years' under specific management practice, $\sigma_{n-1}$ is the standard deviation and $Y^{-1}{ }_{m}$ is the maximum yield obtained under set of practice.

\section{Statistical analyses}

Significance of the treatment effects were determined through analysis of variance ${ }^{72}$. Pooled analysis was done for the grain / seed and stover yields after obtaining the significant differences in coefficient of variance of main and interaction effects over the years with the non-significant interaction effects between the years' and the treatments. Turkey's significant difference test was employed as a post hoc mean analysis at $5 \%$ level of significance using SAS 9.4 (SAS Institute, Cary, NC).

\section{Declarations}

\section{Acknowledgements}

We acknowledge to the Indian Council of Agricultural Research, ICAR-Indian Agricultural Research Institute and the All India Coordinated Research Project (AICRP) on Maize for providing the financial assistance and other facilities. We are thankful to Dr Ompal, Dr Madan Pal, Ms Sakranti, Mr Charan Singh and Mr Jaikisan for their help with the management of crops and lab work.

\section{References}

1. Hobbs, P.R. \& Gupta, R.K. Problems and challenges of no-till farming for the Rice-Wheat systems of the Indo-Gangetic Plains in South Asia. In: Lal, R., Hobbs, P., Uphoff, N., Hansen, D.O. (Eds.), Sustainable Agriculture and the International Rice-Wheat System. Ohio State University; Marcel Dekker, Inc., Columbus, OH, New York, NY, 101-119(2004).

2. Saharawat, Y.S. et al. Evaluation of alternative tillage and crop establishment methods in a rice-wheat rotation in north-western IGP. Field Crops Res. 116, 260-267 (2010).

3. Jat, R.K. et al. Seven years of conservation agriculture in a rice-wheat rotation of eastern Gangetic Plains of South Asia: yield trends and economic profitability. Field Crops Res. 164, 199-210 (2014). 
4. Parihar, C.M. et al. Long-term conservation agriculture and intensified cropping systems: Effects on growth, yield, water, and energy-use efficiency of maize in north-western India. Pedosphere28 (6), 952-963 (2018).

5. Shiferaw, B., Prasanna, B.M., Hellin, J. \& Banziger, M. Crops that feed the world 6 . Past successes and future challenges to the role played by maize in global food security. Food Secur. 3, 30-327 (2011).

6. Srinivasan, G., Zaidi, P.H., Prasanna, B.M., Gonzalez, F. \& Lesnick, K. (Eds.). Proceedings of Eighth Asian Regional Maize Workshop: New Technologies for the New Millennium. Bangkok, Thailand, $5^{\text {th }}-8^{\text {th }}$ August 2002. CIMMYT, Mexico, DF, (2004).

7. Dixit, G.P., Srivastava, A.K. \& Singh, N.P. Marching towards self-sufficiency in chickpea. Sci. 116 (2), 239-242 (2019).

8. Aulakh, M.S. \& Grant, C.A. Integrated nutrient management for sustainable crop production. The Haworth Press, Taylor and Francis Group, New York, 619 (2008).

9. Jat, S.L., Parihar, C.M., Singh, A.K., Jat, M.L. \& Jat, R.K. Carbon sustainability and productivity of maize-based cropping system under conservation agriculture practices in Indo-Gangetic plains. 12 ${ }^{\text {th }}$ Asian Conf. and Exp. Consul. on Maize for Food, Feed, Nutri. \& Env. pp. 204-208 (2014).

10. Parihar, C.M. et al. Conservation agriculture in irrigated intensive maize-based systems of north-western India: effects on crop yields, water productivity and economic profitability. Field Crops Res. 193, 104-116 (2016).

11. Jat, M.L. et al. Crop residue management for sustainable production of maize (Zea Mays) in dryland ecosystem. Sci. Rev. Lett. 6 (23), 1681-1686 (2017).

12. Pooniya, V. et al. Six years of conservation agriculture and nutrient management in maize-mustard rotation: Impact on soil properties, system productivity and profitability. Field Crops Res. 260, 108002 https://doi.org/10.1016/j.fcr.2020.108002.

13. Gathala, M. K. et al. Effect of tillage and crop establishment methods on physical properties of a medium-textured soil under a seven-year rice-wheat rotation. Soil Sci. Soc. Am. J. 75, 1851-1862 (2011).

14. Ladha, J.K. et al. Integrating crop and resource management technologies for enhanced productivity, profitability, and sustainability of the rice-wheat system in South Asia. Integrated crop and resource management in the rice-wheat system of South Asia, pp.69-108 (2009).

15. FAO (Food and Agriculture Organization). Three principles of Conservation Agriculture: http://www.fao.org/conservation-agriculture/en/ (2011).

16. Balwinder-Singh, Humphreys, E., Gaydon, D.S. \& Yadav, S. Options for increasing the productivity of the rice-wheat system of north-west India while reducing groundwater depletion Part 2. Is conservation agriculture the answer? Field Crops Res. 173, 81-94 (2015).

17. Laik, R. et al. Integration of conservation agriculture with best management practices for improving system performance of the rice-wheat rotation in eastern Indo-Gangetic plains of India. Ecosys. Environ. 195, 68-82 (2014).

18. Govaerts, B. et al. Conservation agriculture as a sustainable option for the central Mexican highlands. Soil Till. Res. 103, 222-230 (2009).

19. Jat, M. L. et al. Double no-till and permanent raised beds in maize-wheat rotation of north western Indo-Gangetic plains of India: Effects on crop yields, water productivity, profitability and soil physical properties. Field Crop Res. 149, 291-299 (2013).

20. Ludwig, B. et al. Effects of fertilization and soil management on crop yields and carbon stabilization in soils. A review. Agronomy for Sustainable Dev. 31, 361-372 (2011).

21. Powlson, D.S., Stirling, C.M., Thierfelder, C., White, R.P. \& Jat, M.L. Does conservation agriculture deliver climate change mitigation through soil carbon sequestration in tropical agro- ecosystems? Eco. \& Envi.220, 164-174 (2016).

22. Kandeler, E. et al. Response of soil microbial biomass and enzyme activities to the transient elevation of carbon dioxide in semi-arid grassland. Soil Biol. Biochem. 38, 2448-2460 (2006).

23. Witt, C. J. M., Pasuquin, M. F., Pampolino, R. J., Buresh, A. \& Dobermann, A. A manual for the development and participatory evaluation of site-specific nutrient management for maize in tropical, favorable environments. Available at http://seap.ipni.net, 30 (2009).

24. Pampolino, M. et al. Development and evaluation of nutrient expert for wheat in South Asia (special issue): Nutrient management for wheat. Better Crops96 (3), 29-31(2012).

25. Johnston, A. M. Nutrient Expert-Going global with improved fertilizer recommendations. Better Crops-South Asia. 30, (2014).

26. Sapkota, T.B. et al. Precision nutrient management in conservation agriculture based wheat production system of north-west India: Profitability, nutrient use efficiency and environmental footprint. Field Crop Res. 155, 233-244 (2014).

27. Pooniya, V. et al. 'Nutrient expert' assisted site-specific-nutrient-management: An alternative precision fertilization technology for maize-wheat cropping system in South-Asian Indo-Gangetic Plains. Indian J. of Agril. Sci. 85 (8), 996-1002 (2015).

28. Budhathoki, S. et al. Assessing growth, productivity and profitability of drought tolerant rice using nutrient expert-rice and other precision fertilizer management practices in Lamjung, Nepal. Sci. Agric. 153-158 (2018).

29. Satyanarayana, T. et al. Economics of nitrogen fertilizer application in rice, wheat and maize grown in the Indo-Gangetic Plains. Indian J. of Fert. 8(8), 6271 (2012).

30. Satyanarayana, T., Majumdar, K., Pampolino, M., Johnston, A.M. \& Jat, M.L. Nutrient Expert ${ }^{\mathrm{TM}}$ : A tool to optimize nutrient use and improve productivity of maize. Better Crops. South Asia 97 (1), 21-24 (2013).

31. Annual progress report kharif maize 2016. All India coordinated research project on maize (AICRPM). Indian institute of maize research, PAU campus, Ludhiana, India. pp. 1082 (2016).

32. Abrol, I. P. \& Sangar, S. Sustaining Indian agriculture-conservation agriculture the way forward. Sci. 91, 1020-2015 (2006).

33. Ghosh, P. K. et al. Conservation agriculture towards achieving food security in north-east Curr. Sci. 99, 915-21 (2010).

34. Parihar, C.M. et al. Soil quality and carbon sequestration under conservation agriculture with balanced nutrition in intensive cereal-based system. Soil and Tillage Res. 202,104653 (2020). 
35. Mahajan, G., Singh, K. \& Gill, M.S. Scope for enhancing and sustaining rice productivity in Punjab (food bowl of India). J. Agric. Res. 7, $5611-5620$ (2012).

36. Jat, H. S. et al. Effects of tillage, crop establishment and diversification on soil organic carbon, aggregation, aggregate associated carbon and productivity in cereal systems of semi-arid Northwest India. Soil Till. Res. 190, 128-138 (2019).

37. Jat, H.S. et al. Assessing soil properties and nutrient availability under conservation agriculture practices in a reclaimed sodic soil in cereal-based systems of North-West India. Agron. Soil Sci.64, 531-545 (2018).

38. Kaschuk, G., Alberton, O. \& Hungria, M. Three decades of soil microbial biomass studies in Brazilian ecosystems: lessons learned about soil quality and indications for improving sustainability. Soil Biol. Biochem. 42, 1-13 (2010).

39. Sarkar, D. et al. Can sustainability of maize-mustard cropping system be achieved through balanced nutrient management? Field Crops Res. 225, 921(2018).

40. Pooniya, V., Palta, J.A., Chen, Y., Delhaize, E. \& Siddique, K.H.M. 2019. Impact of the TaMATE1B gene on above and below-ground growth of durum wheat grown on an acid and Al3+-toxic soil. Plant Soil447, 73-84 (2020).

41. Pasuquin, J.M. et al. Closing yield gaps in maize production in Southeast Asia through site-specific nutrient management. Field Crops Res.156, 219-230 (2014).

42. Choudhary, K.M. et al. Evaluating alternatives to rice-wheat system in western Indo-Gangetic Plains: Crop yields, water productivity and economic profitability. Field Crop Res. 218, 1-10 (2018).

43. Jat, R. K. et al. Ten years of conservation agriculture in a rice-maize rotation of Eastern Gangetic Plains of India: Yield trends, water productivity and economic profitability. Field Crop Res. 232, 1-10 (2019).

44. Jat, H.S. et al. Designing profitable, resource use efficient and environmentally sound cereal based systems for the Western Indo-Gangetic plains. reports, 10(1), 1-16 (2020).

45. Thierfelder, C., Amezquita, E. \& Stahr, K. Effects of intensifying organic manuring and tillage practices on penetration resistance and infiltration rate. Soil Till. Res. 82, 211-226 (2005).

46. Bescansa, P., Imaz, M., Virto, I., Enrique, A. \& Hoogmoed, W.B. Soil water retention as affected by tillage and residue management in semiarid Spain. Soil Till. Res. 87, 19-27 (2006).

47. Lal, R. Sequestering carbon and increasing productivity by conservation agriculture. 70, 55A-62A (2015).

48. Page, K.L., Dang, Y.P. \& Dalal, R.C. The ability of conservation agriculture to conserve soil organic carbon and the subsequent impact on soil physical, chemical, and biological properties and yield. Sustain. Food Syst. 4, 31 (2020).

49. Six, J., Elliott, E. T., \& Paustian, K. Soil macroaggregate turnover and microaggregate formation: a mechanism for $\mathrm{C}$ sequestration under no-tillage agriculture. Soil Bio. Biochem. 32, 2099-2103 (2000).

50. Tan, Z., Lal, R., Owens, L. \& Izaurralde, R.C. Distribution of light and heavy fractions of soil organic carbon as related to land use and tillage practice. Soil Till. Res. 92, 53-59 (2007).

51. Blanco-Canqui, H. \& Ruis, S. J. No-tillage and soil physical environment. Geoderma326, 164-200 (2018).

52. Somasundaram, J. et al. Conservation agriculture effects on soil properties and crop productivity in a semiarid region of India. Soil Res. 57, 187-199 (2019).

53. Hansen, N. C., Allen, B. L., Baumhardt, R. L., \& Lyon, D. J. Research achievements and adoption of no-till, dryland cropping in the semi-arid U.S. Great Plains. Field Crops Res. 132, 196-203 (2012).

54. Dalal, R. C., Wang, W., Allen, D. E., Reeves, S. \& Menzies, N. W.. Soil nitrogen and nitrogen-use efficiency under long-term no-till practice. Soil Sci. Society Am. J. 75, 2251-2261 (2011). Zhang, H., Lal, R., Zhao, X., Xue, J., \& Chen, F. Opportunities and challenges of soil carbon sequestration by conservation agriculture in China. Agron. 124, 1-36 (2014).

55. Zhang, H.L., Lal, R., Zhao, X., Xue, J.F. \& Chen, F. Opportunities and challenges of soil carbon sequestration by conservation agriculture in China. In Advances in agronomy 124, 1-36 (2014).

56. Mandal, A., Patra, A.K., Singh, D., Swarup, A. \& Masto RE. Effect of long-term application of manure and fertilizer on biological and biochemical activities in soil during crop development stages. Biores Tech. 98, 3585-3592 (2007).

57. Singh, G., Kumar, D., Marwaha, T.S., Singh, A.K. \& Srinivasmurthy, K. Conservation tillage and integrated nitrogen management stimulates soil microbial properties under varying water regimes in maize-wheat cropping system in northern India. Archives of Agro. \& Soil Sci.57(5), 507-521 (2011).

58. Manning, D.A.C. \& Renforth, P. Passive sequestration of atmospheric $\mathrm{CO}_{2}$ through coupled plant mineral reactions in urban soils. Sci. Technol. 47, $135-141$ (2013).

59. Mullen, M., Melhorn, C., Tyler, C. \& Duck, D. Biological and biochemical soil properties in no-till corn with different cover crops. Soil Water Conserv. 5, 219224 (1998).

60. Pooniya, V. \& Shivay, Y.S. Summer green-manuring crops and zinc fertilization on productivity and economics of basmati rice (Oryza sativa L.). Agron. Soil. Sci. 58 (6), 593-616 (2012).

61. Pooniya et al. Influence of summer legume residue-recycling and varietal diversification on productivity, energetics and nutrient dynamics in basmati rice-wheat cropping system of western Indo-Gangetic Plains. Journal of plant Nutrition41(12), 1491-1506 (2018).

62. Pooniya, V., Shivay, Y. S., Rana, A., Nain, L. \& Prasanna, R. Enhancing soil nutrient dynamics and productivity of Basmati rice through residue incorporation and zinc fertilization. J. Agron. 41, 28-37 (2012). 
63. Walkley, A.J. \& Black, I.A. An examination of the Degtjareff method for determination of soil organic matter and a proposed modification of the chromic acid titration method. Soil Sci. 37, 29-38 (1934).

64. Subbiah, B.V \& Asija, G. L. A rapid procedure for estimation of the available nitrogen in soil. Sci. 25, 259-260 (1956).

65. Olsen, S.R., Cole, C.V., Watanabe, F.S. \& Dean, L. Estimation of available phosphorus in soil by extraction with sodium carbonate. USDA, Washington, Conc. 933 (1954).

66. Hanway, J.J. \& Heidel, H. Soil analysis methods as used in lowa state college soil testing laboratory, bulletin 57. lowa State College of Agriculture, USA, 131 (1952).

67. Babu, S. et al. Impact of land configuration and organic nutrient management on productivity, quality and soil properties under baby corn in Eastern Himalayas. Reports, 10(1), 1-14 (2020).

68. Vance, E.D., Brookes, P.C. \& Jenkinson, D.S. An extraction method for measuring soil microbial biomass carbon. Soil Biol. Biochem. 19, 703-704 (1987).

69. Bhushan, L. et al. Saving of water and labor in a rice-wheat system with no-tillage and direct seeding technologies. J. 99, 1288-1296 (2007).

70. Singh, R.P., Das, S.K., Bhaskara Rao, U.M. \& Reddy, N. Towards sustainable dryland agricultural practices (CRIDA, Hyderabad, 1990).

71. Wanjari, R.H., Singh, M.V. \& Ghosh, P.K. Sustainable yield index: An approach to evaluate the sustainability of long-term intensive cropping systems in India. of Sustainable Agric.24(4), 39-56 (2004).

72. Gomez, K.A. \& Gomez, A.A. Statistical procedures for agricultural research $2^{\text {nd }}$ edn, 180-209 (Wiley, New York, 1984).

\section{Tables}

Table 1 Description of the crop establishment practices (CEP) and nutrient management adopted in the maize-chickpea rotation during the seven years' of experimentation.

\begin{tabular}{|c|c|c|c|}
\hline $\begin{array}{l}\text { S. } \\
\text { No. }\end{array}$ & Treatment & $\begin{array}{l}\text { Treatment } \\
\text { notations }\end{array}$ & Residue/nutrient management \\
\hline 1 & Zero till flat bed & ZTFB & $\begin{array}{l}\text { Chickpea (root stubbles }+ \text { above ground) residues } \sim 2.5 \mathrm{Mg} \mathrm{ha}^{-1} \text { and maize } \\
\text { stubbles of } \sim 0.40 \mathrm{~m} \text { height from ground were retained }\end{array}$ \\
\hline 2 & $\begin{array}{l}\text { Permanent beds }(0.37 \mathrm{~m} \text { beds and } 0.30 \mathrm{~m} \\
\text { furrows) }\end{array}$ & PNB & $\begin{array}{l}\text { Chickpea (root stubbles }+ \text { above ground) residues } \sim 2.5 \mathrm{Mg} \mathrm{ha}^{-1} \text { and maize } \\
\text { stubbles of } \sim 0.40 \mathrm{~m} \text { height from ground were retained. }\end{array}$ \\
\hline 3 & Conventional tillage & CT & Full residue removed and conventional tillage practices followed \\
\hline 4 & Farmers fertilizers practice & FFP & Maize:110:13:2.0 kg NPK ha-1; chickpea: 18:20:0 kg NPK ha-1 \\
\hline 5 & Recommended dose of fertilizers & RDF & Maize: 150:26.2:50 kg NPK ha-1; chickpea: 20:26.2:16.6 kg NPK ha-1 \\
\hline 6 & $\begin{array}{l}\text { Nutrient expert assisted: site-specific nutrient } \\
\text { management (seven years' mean) }\end{array}$ & $\mathrm{NE} \circledast$ & Maize: 130:19.5:55 kg NPK ha-1; chickpea: 20:26.2:16.6 kg NPK ha-1 \\
\hline
\end{tabular}

Table 2 Seven years' mean grain / seed and stover yields $\left(\mathrm{Mg} \mathrm{ha}^{-1}\right)( \pm$ S.D.) and sustainable yield index (SYI) under the CA-based CEP and nutrient management in the maize-chickpea rotation.

\begin{tabular}{|lllllll|}
\hline \multirow{2}{*}{ Treatment } & Maize & & \multicolumn{3}{l|}{ Chickpea } \\
\cline { 2 - 6 } & Grain & Stover & SYI & Seed & Stover & SYI \\
CET practices & & & & & \\
\hline ZTFB & $4.34^{\mathrm{a}{ }^{\sharp} \pm 0.33}$ & $7.22^{\mathrm{a}} \pm 0.63$ & $0.91^{\mathrm{a}}$ & $1.41^{\mathrm{b}} \pm 0.69$ & $4.58^{\mathrm{b}} \pm 0.56$ & $0.78^{\mathrm{b}}$ \\
\hline PNB & $4.37^{\mathrm{a}} \pm 0.40$ & $7.24^{\mathrm{a}} \pm 0.43$ & $0.93^{\mathrm{a}}$ & $1.58^{\mathrm{a}} \pm 0.70$ & $4.87^{\mathrm{a}} \pm 0.57$ & $0.89^{\mathrm{a}}$ \\
\hline CT & $3.79^{\mathrm{b}} \pm 0.29$ & $6.34^{\mathrm{b}} \pm 0.69$ & $0.79^{\mathrm{b}}$ & $1.24^{\mathrm{c}} \pm 0.48$ & $4.08^{\mathrm{c}} \pm 0.44$ & $0.68^{\mathrm{c}}$ \\
\hline Nutrient management & & & & & \\
FFP & $3.44^{\mathrm{c}} \pm 0.46$ & $5.84^{\mathrm{c}} \pm 0.81$ & $0.61^{\mathrm{c}}$ & $1.31^{\mathrm{b}} \pm 0.63$ & $4.06^{\mathrm{c}} \pm 0.60$ & $0.82^{\mathrm{c}}$ \\
\hline RDF & $4.43^{\mathrm{a}} \pm 0.30$ & $7.09^{\mathrm{b}} \pm 0.55$ & $0.82^{\mathrm{a}}$ & $1.43^{\mathrm{a}} \pm 0.65$ & $4.43^{\mathrm{b}} \pm 0.56$ & $0.90^{\mathrm{a}}$ \\
\hline NE® & $4.63^{\mathrm{a}} \pm 0.29$ & $7.87^{\mathrm{a}} \pm 0.41$ & $0.86^{\mathrm{a}}$ & $1.49^{\mathrm{a}} \pm 0.57$ & $5.03^{\mathrm{a}} \pm 0.42$ & $0.94^{\mathrm{a}}$ \\
\hline
\end{tabular}

\#Means followed by a similar uppercase letters within a column are not significantly different $(p<0.05)$ according to Tukey's HSD test.

Table 3 Interaction effect of the CA-based CEP and nutrient management on the system productivity ( \pm S.D.) in terms of MGEY during the seven years' of the study in the maize-chickpea rotation. 


\begin{tabular}{|c|c|c|c|c|c|c|c|}
\hline \multirow[t]{2}{*}{ Treatment } & \multicolumn{7}{|c|}{ Maize grain equivalent yield (MGEY, $\mathrm{Mg} \mathrm{ha}^{-1}$ ) } \\
\hline & $2013-14$ & 2014-15 & $2015-16$ & $2016-17$ & 2017-18 & $2018-19$ & $2019-20$ \\
\hline ZTFB-FFP & $6.35^{\mathrm{cde}_{ \pm}} \pm .31$ & $5.39^{c} \pm 0.12$ & $3.79^{d} \pm 0.66$ & $6.33^{\text {bcde }_{ \pm}} \pm 1.18$ & $9.18^{\mathrm{cd}} \pm 1.23$ & $9.5^{\mathrm{b}} \pm 0.52$ & $8.51^{c} \pm 0.45$ \\
\hline ZTFB-RDF & $6.76^{\mathrm{cd}} \pm 0.15$ & $6.26^{\mathrm{abc}} \pm 0.69$ & $5.48^{\mathrm{abc}} \pm 0.36$ & $7.84^{\mathrm{ab}} \pm 0.80$ & $11.5^{\mathrm{ab}} \pm 1.54$ & $10.9^{\mathrm{a}} \pm 0.40$ & $11.2^{b c} \pm 0.88$ \\
\hline ZTFB-NE® & $7.54^{b c} \pm 0.37$ & $6.82^{\mathrm{ab}} \pm 1.10$ & $6.08^{\mathrm{ab}} \pm 0.60$ & $8.83^{a} \pm 0.85$ & $12.3^{\mathrm{a}} \pm 0.69$ & $11.1^{\mathrm{a}} \pm 0.41$ & $14.4^{\mathrm{a}} \pm 4.59$ \\
\hline PNB-FFP & $5.82^{\mathrm{de}_{ \pm 0}}+07$ & $5.49^{b c} \pm 0.30$ & $4.56^{\mathrm{bcd}} \pm 0.71$ & $5.79^{\mathrm{de}_{ \pm 1}} \pm 2$ & $10.4^{\mathrm{bc}} \pm 1.21$ & $10.9^{\mathrm{a}} \pm 0.77$ & $10.1^{b c} \pm 0.84$ \\
\hline PNB-RDF & $9.07^{\mathrm{ab}} \pm 0.12$ & $6.63^{a b c} \pm 0.67$ & $6.72^{\mathrm{a}} \pm 0.87$ & $6.93^{\mathrm{bcd}} \pm 1.67$ & $11.8^{\mathrm{ab}} \pm 1.26$ & $11.3^{\mathrm{a}} \pm 0.43$ & $11.1^{\mathrm{bc}} \pm 0.51$ \\
\hline PNB-NE® & $9.54^{\mathrm{a}} \pm 0.77$ & $7.48^{\mathrm{a}} \pm 0.34$ & $6.79^{a} \pm 0.70$ & $7.81^{a b c} \pm 0.91$ & $11.5^{\mathrm{ab}} \pm 1.27$ & $11.6^{\mathrm{a}} \pm 0.72$ & $12.3^{\mathrm{ab}} \pm 0.40$ \\
\hline CT-FFP & $4.96^{\mathrm{e}} \pm 0.96$ & $5.77^{b c} \pm 1.64$ & $4.48^{\mathrm{cd}} \pm 0.84$ & $5.13^{e} \pm 0.61$ & $9.12^{\mathrm{cd}} \pm 1.43$ & $7.87^{c} \pm 0.29$ & $9.16^{c} \pm 0.5$ \\
\hline CT-RDF & $7.93^{\mathrm{abc}} \pm 0.75$ & $6.01^{b c_{ \pm}} \pm .13$ & $5.81^{\mathrm{abc}} \pm 1.07$ & $6.11^{\mathrm{cde}_{ \pm}} \pm .70$ & $9.64^{\mathrm{cd}} \pm 1.23$ & $8.27^{c} \pm 0.09$ & $8.73^{\mathrm{c}} \pm 1.07$ \\
\hline CT-NE® & $7.48^{b c} \pm 0.19$ & $6.29^{a b c} \pm 0.29$ & $5.82^{a b c} \pm 0.68$ & $6.84^{\mathrm{bcde}_{ \pm}} \pm .49$ & $8.34^{d} \pm 0.81$ & $7.89^{c} \pm 0.37$ & $9.16^{c} \pm 0.49$ \\
\hline
\end{tabular}

Means followed by a similar uppercase letters within a column are not significantly different $(p<0.05)$ according to Tukey's HSD test.

Table 4 Economics of the maize-chickpea rotation under the CA-based CEP and nutrient management during the seven years' of the study.

\begin{tabular}{|c|c|c|c|c|c|c|c|c|c|c|c|c|}
\hline \multirow[t]{2}{*}{ Treatment } & \multicolumn{7}{|c|}{ Production costs (US\$ ha ${ }^{-1}$ year $^{-1}$ ) } & \multicolumn{5}{|c|}{ System net returns over production costs (US\$ r } \\
\hline & $\begin{array}{l}2013- \\
14\end{array}$ & $\begin{array}{l}2014- \\
15\end{array}$ & $\begin{array}{l}2015- \\
16\end{array}$ & $\begin{array}{l}2016- \\
17\end{array}$ & $\begin{array}{l}2017- \\
18\end{array}$ & $\begin{array}{l}2018- \\
19\end{array}$ & $\begin{array}{l}2019- \\
20\end{array}$ & $\begin{array}{l}2013- \\
14\end{array}$ & $\begin{array}{l}2014- \\
15\end{array}$ & $\begin{array}{l}2015- \\
16\end{array}$ & $\begin{array}{l}2016- \\
17\end{array}$ & $\begin{array}{l}2017- \\
18\end{array}$ \\
\hline \multicolumn{13}{|c|}{ CET practices } \\
\hline ZTFB & $470^{c}$ & $513^{\mathrm{c}}$ & $517^{\mathrm{C}}$ & $508^{\mathrm{C}}$ & $580^{c}$ & $532^{\mathrm{c}}$ & $601^{c}$ & $1104^{b}$ & $945^{a b}$ & $754^{a}$ & $1672^{\mathrm{a}}$ & $2086^{a}$ \\
\hline PNB & $476^{\mathrm{b}}$ & $520^{\mathrm{b}}$ & $525^{\mathrm{b}}$ & $516^{\mathrm{b}}$ & $585^{b}$ & $548^{\mathrm{b}}$ & $622^{\mathrm{b}}$ & $1362^{\mathrm{a}}$ & $1025^{\mathrm{a}}$ & $865^{\mathrm{a}}$ & $1513^{b}$ & $2126^{a}$ \\
\hline CT & $554^{a}$ & $614^{a}$ & $630^{a}$ & $621^{a}$ & $694^{a}$ & $642^{\mathrm{a}}$ & $724^{a}$ & $979^{c}$ & $805^{b}$ & $575^{b}$ & $1327^{\mathrm{c}}$ & $1499^{b}$ \\
\hline \multicolumn{13}{|c|}{ Nutrient management } \\
\hline FFP & $475^{\mathrm{c}}$ & $525^{c}$ & $535^{c}$ & $530^{c}$ & $609^{c}$ & $563^{c}$ & $636^{c}$ & $828 b$ & $775^{\mathrm{b}}$ & $479^{b}$ & $1263^{c}$ & $1707^{b}$ \\
\hline RDF & $516^{a}$ & $565^{a}$ & $573^{a}$ & $560^{a}$ & $626^{a}$ & $581^{a}$ & $658^{a}$ & $1269 a$ & $926^{a b}$ & $804^{a}$ & $1527^{b}$ & $2018^{a}$ \\
\hline $\mathrm{NE} \circledast$ & $508^{b}$ & $556^{\mathrm{b}}$ & $564^{\mathrm{b}}$ & $554^{\mathrm{b}}$ & $624^{a}$ & $578^{a}$ & $653^{a}$ & $1349 a$ & $1074^{a}$ & $911^{a}$ & $1723^{a}$ & $1986^{a}$ \\
\hline
\end{tabular}

Means followed by a similar uppercase letters within a column are not significantly different $(p<0.05)$ according to Tukey's HSD test. Price of one US $\$=62.9$ INR2013-14; 60.9 INR2014-15; 64.2 INR2015-16; 68 INR2016-17; 64 INR2017-18; 74 INR2018-19; 70 INR2019-20

\section{Figures}




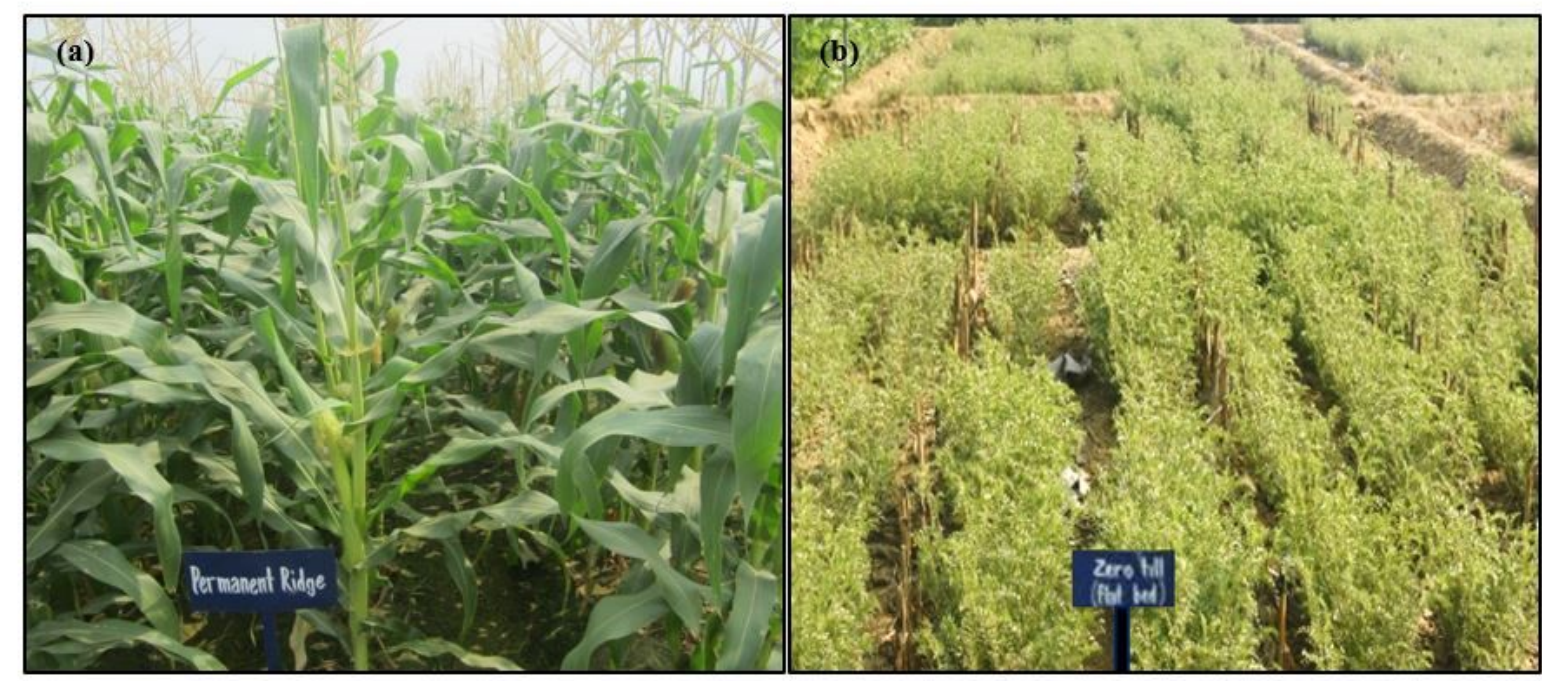

Figure 1

Maize-chickpea rotation under the CA and nutrient management - PNB maize (a) and ZTFB chickpea (b).

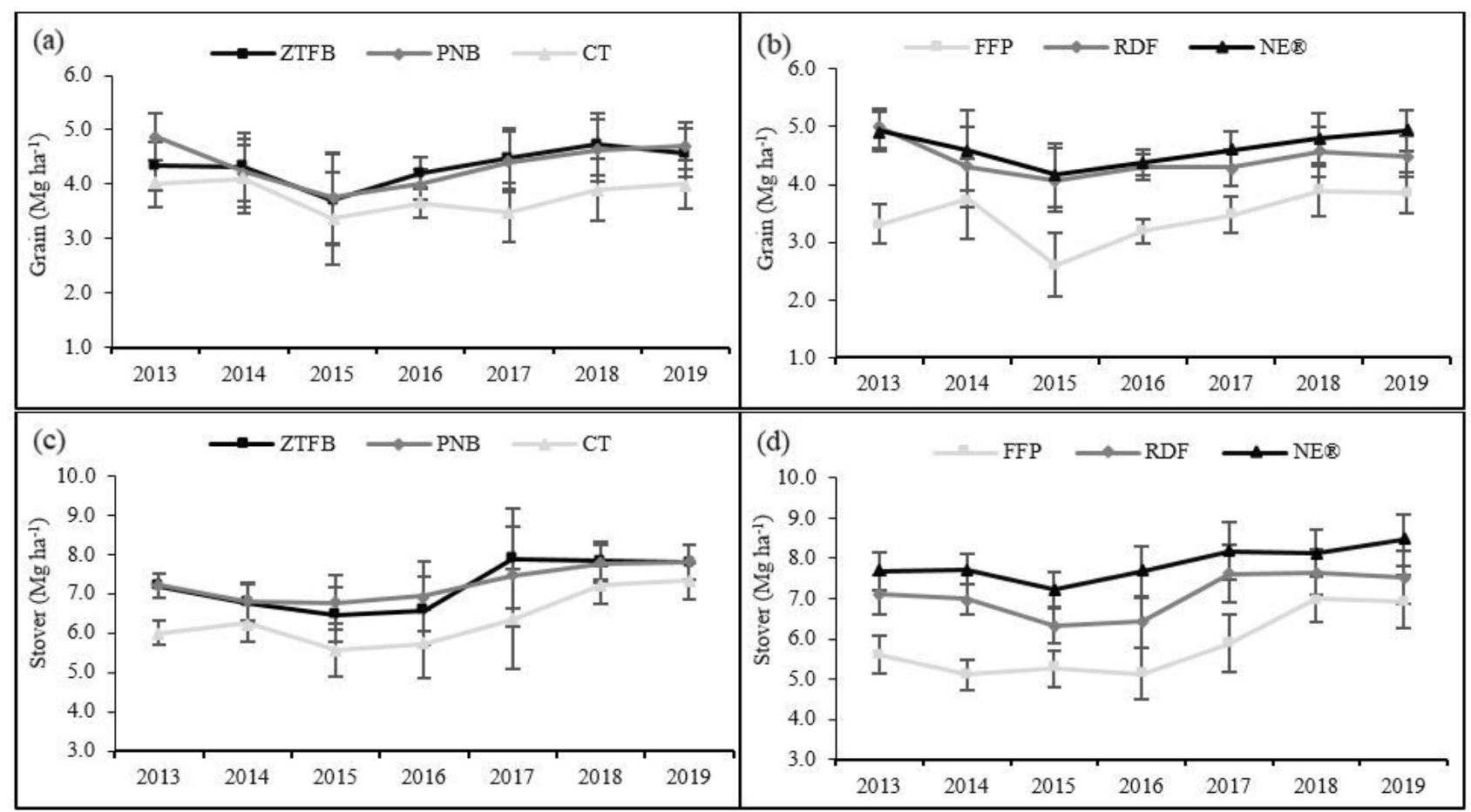

Figure 2

Seven years' grain $(a, b)$ and stover $(c, d)$ yields trend of the maize under the CA-based CEP and nutrient management in the maize-chickpea rotation. The vertical bars indicate the LSD at $p=0.05$. 

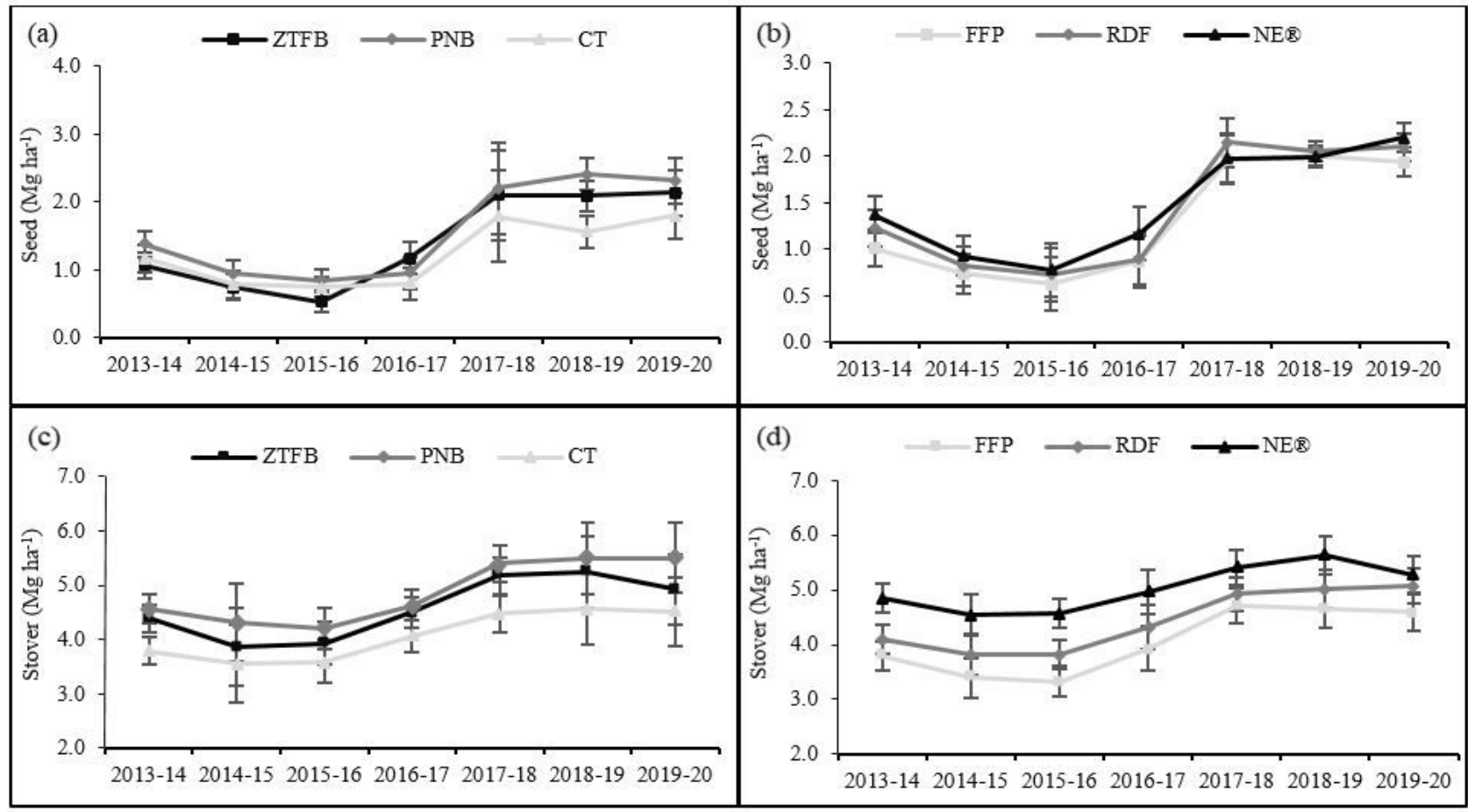

\section{Figure 3}

Seven years' seed $(a, b)$ and stover $(c, d)$ yields trend of the chickpea under the CA-based CEP and nutrient management in the maize-chickpea rotation. The vertical bars indicate the LSD at $p=0.05$.

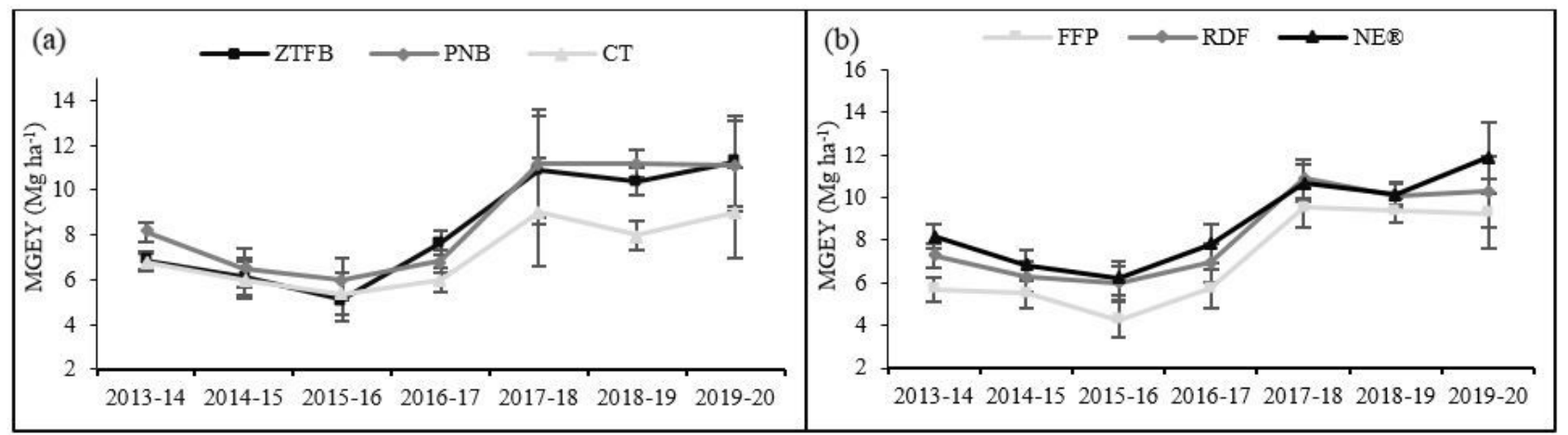

\section{Figure 4}

Seven years' trend in the MGEY $(a, b)$ under the CA-based CET and nutrient management in the maize-chickpea rotation. The vertical bars indicate the LSD at $\mathrm{p}=0.05$.

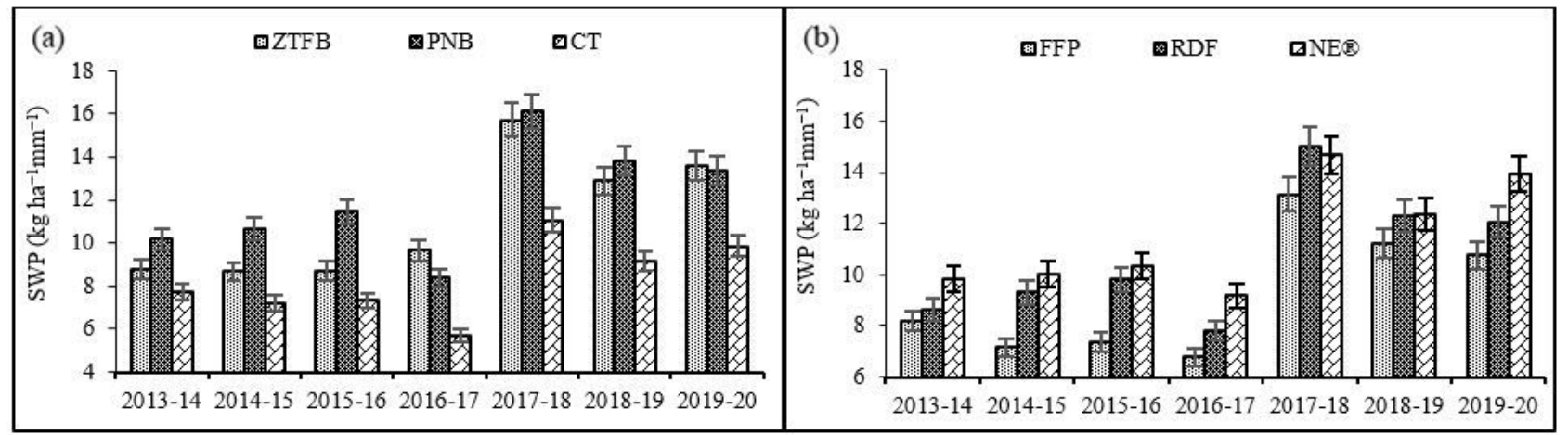


Figure 5

Seven years' trends of SWP $(a, b)$ in the CA-based CEP and nutrient management under the maize-chickpea rotation. The vertical bars indicate the LSD at $\mathrm{p}=0.05$.

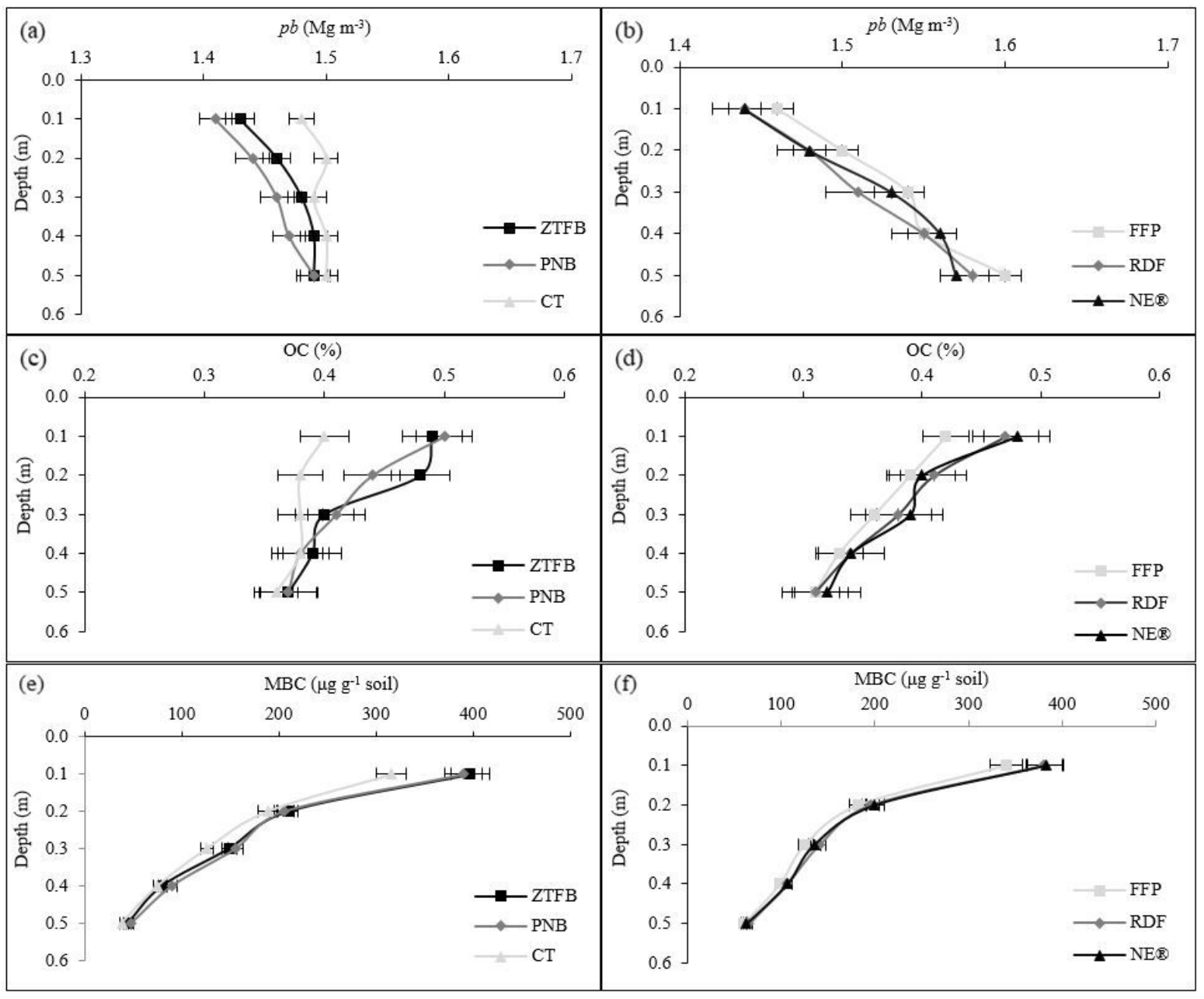

Figure 6

Soil pb $(a, b), O C(c, d)$ and MBC $(e, f)$ under the CA-based CEP and nutrient management after 7th season maize in the maize-chickpea rotation. The horizontal bars indicate the LSD at $p=0.05$.

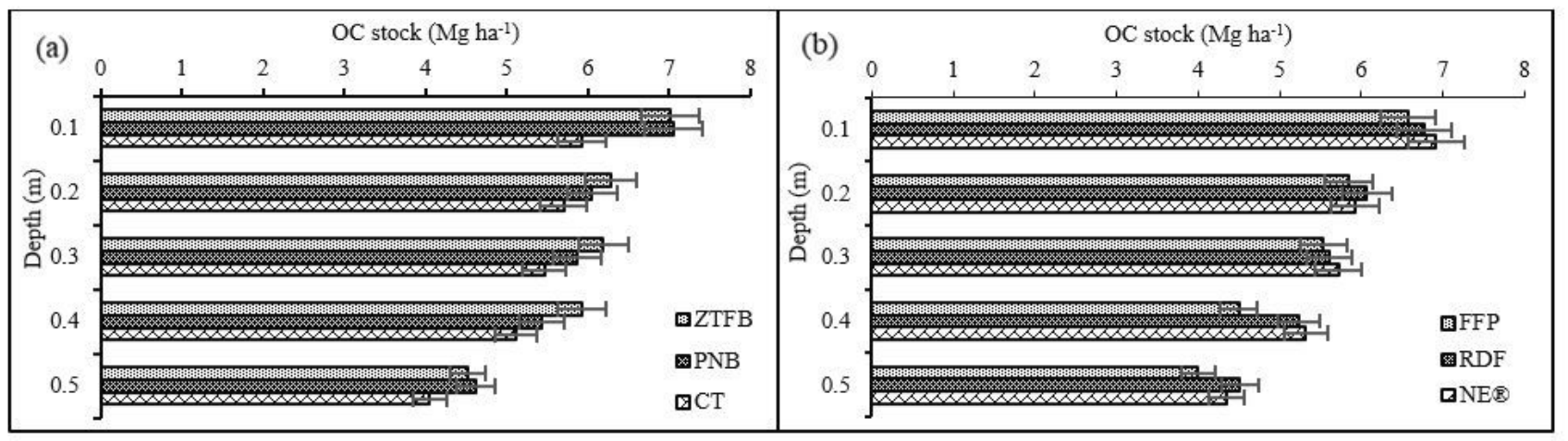

\section{Figure 7}

Seven years' trends of OC stock $(a, b)$ under the CA-based CEP and nutrient management in the maize-chickpea rotation. The vertical bars indicate the LSD at $p=0.05$. 


\section{Supplementary Files}

This is a list of supplementary files associated with this preprint. Click to download.

- Supplementarytable.docx 